\title{
SWOT Analysis of Disinfection Products under the New Crown Epidemic
}

\author{
Peilun Zhang ${ }^{1}$ \\ ${ }^{1}$ Central University of Finance and Economics Beijing, China
}

\begin{abstract}
In 2020, the new crown epidemic broke out globally, and the demand for disinfection products at home and abroad became strong, especially the demand for daily home disinfection products has increased significantly. This article uses quantitative and qualitative research methods to study the development status and opportunities of disinfection products. The findings of this article includes that firstly, under the influence of the novel coronavirus pneumonia epidemic, there will be strong market demand for disinfection products and related derivatives in 2020; secondly, the epidemic will drive short-term market output growth; thirdly, the impact of the new crown epidemic will further cultivate the market's disinfection and antivirus usage habits and promote the long-term development of the industry. At the end of the article, it also puts forward some strategic suggestions for the government and enterprises to deal with the normalization of the epidemic, and provides guidance for the government and enterprises. The research in this article is of great significance to the development of the disinfection product industry, and the corporate strategy mentioned in this article has certain theoretical value.
\end{abstract}

\section{Introduction}

On January 20, 2020, the pneumonia epidemic caused by the new coronavirus was widely concerned by all walks of life. Based on previous knowledge of coronaviruses, all the classic disinfection methods should be able to kill the coronavirus. According to the recommendations given by the National Health Commission, the current disinfectant that can effectively kill the virus is mainly mediumefficient disinfectant, and the main focus products are 84 disinfectant (sodium hypochlorite), medical alcohol and hand disinfectant. Therefore, in order to avoid contracting the new coronavirus, people buy many disinfection products for daily disinfection.

In social market, competition is becoming more and more fierce, and corporate strategic management methods will be closely linked to the overall development of the company. Therefore, it is urgent for companies to improve their own strategic management. So far, the competition strategy of enterprises has a history of decades of research. It is a strategy for the overall, long-term, and basic problems in enterprise competition. The market environment for enterprises is unprecedentedly fierce competition. How to develop in the competition is a topic that every enterprise is thinking about. Some scholars believe that through the effect of corporate strategy evolution and innovation paradigm on capability evolution, more and more latecomers have completed the accumulation of better knowledge and capabilities, helping them to establish differentiated competition advantages in international market competition [1]. Some scholars believe that in the future development of corporate strategic management theory, strategic analysis models should be more objective and dynamic in order to respond to changes in the environment and be more widely used in corporate strategy formulation [2]. Among them, the SWOT analysis model is an effective method for formulating corporate strategy. Its core idea is to combine the internal and external environment of the company as the basis for strategy formulation. By systematically analyzing the four aspects of the internal strengths, weaknesses, opportunities, and threats, a comprehensive strategy suitable for the development of the enterprise is selected. Some scholars believe that the SWOT analysis method uses systematic analysis concepts to comprehensively analyze the company's internal resource advantages, disadvantages, and market development environment, as well as list the current obstacles and facilitating factors in the development of the company. Enterprise strategic management is more scientific and comprehensive, which can have an important impact on the development of the enterprise [3]. Some scholars believe that SWOT analysis can clearly see the advantages, disadvantages, opportunities, and threats of enterprises, from which the current status of the entire industry [4].

This article focuses on the research on the status quo of the development of disinfection products during the epidemic and the trend of future development. It will conduct in-depth research on the samples of disposable disinfectants, medical alcohol, and hand disinfectants. The SWOT analysis method is the main analysis method of this article. At the end of the article, the corresponding conclusions are drawn based on the current status of 
disinfection products and future development trends. The corresponding suggestions are put forward at the enterprise and government levels.

\section{Data and Method}

\subsection{Data}

The data in this study include sample data, such as handwashing disinfectant, 84 disinfectant, $75 \%$ medical alcohol, mainly from the CCID Media Data Center, which belongs to the China Electronic Information Industry Development Research Institute, and the data comes from the national statistical agency has abundant data and large sample size, with the sample period from 2015 to July 2020.

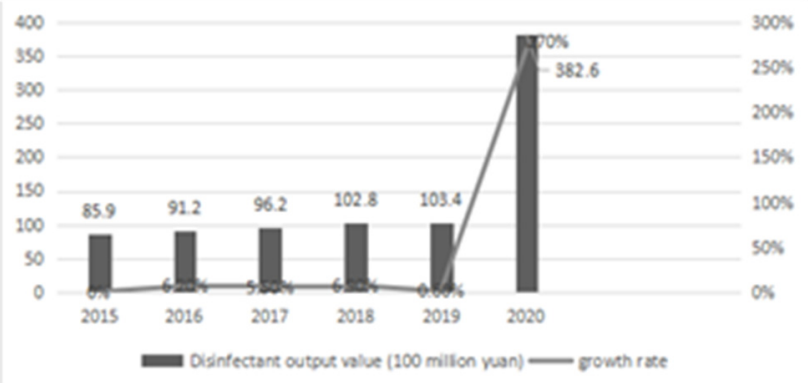

Fig1. 2015-2020 disinfectant market output value and forecast value. (Data source: CCID, iiMedia Data Center)

In recent years, China's disinfectant market has been developing steadily at an annual growth rate of 5.5\%. Affected by the chemical industry, the growth rate in 2019 has slowed down, with an output value of 10.34 billion yuan, an increase of $0.6 \%$ year-on-year, and the growth rate decreased by 6.3 percentage points from the previous year. After the outbreak of the epidemic, the sales of hand sanitizers soared by $2315 \%$ but from the perspective of application fields, most of the disinfectants are used in agriculture, medicine, industry and other fields. Among them, the total output value of disinfectants in the agricultural and medical fields accounts for up to $45 \%$, followed by the industrial sector, accounting for $17 \%$. The supply of disinfection products exceeds demand. In order to meet market demand, the prices of all products have been adjusted to varying degrees. Among them, close to $30 \%$ of the disinfectant and disinfection equipment will increase within $20 \%$, and the price of $30 \%$ of the disinfectant and disinfection equipment will increase by $20-50 \%$. There are still some products that have not increased in price, and even have a slight price reduction trend.

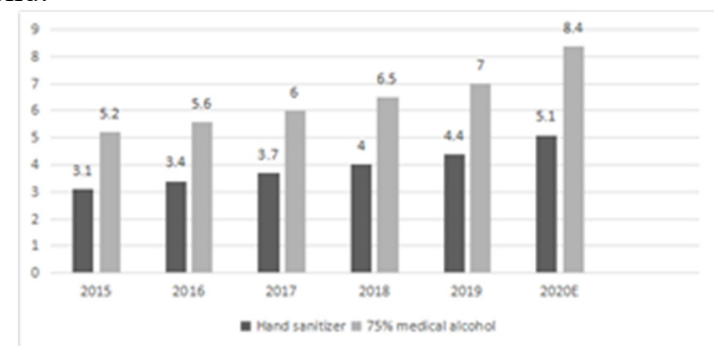

Fig2. 2015-2020 China's hand disinfectant and 75\% medical alcohol production trend chart. (Data source: CCID, iiMedia Data Center)
In March and April 2020, the sales of aerosol disinfectants increased by $230.5 \%$ over the same period last year, and the sales of multifunctional cleaners also increased by $109.1 \%$. As for April 30, 2020, the daily production capacity of medical protective clothing was 1.89 million sets, and the daily output was 800,000 sets, an increase of 90.6 times from the beginning of the epidemic (end of January); among the disinfection products, the daily production capacity of hand sanitizer was 409 tons, 308 tons per day, an increase of 2.6 times compared to the initial period of the epidemic. The growth multiple of 84 disinfectant and the hand-washing disinfectant liquid is relatively small, only 1.6 times of the initial period of the epidemic. The daily production capacity is 366,000 boxes, and the daily output is 117,000 boxes; the daily production capacity of automatic infrared thermometers is 10,700 units, and the daily output is 3,400 units, of which the daily output increased by $233 \%$ from the beginning of the epidemic; the daily production capacity of new coronavirus detection reagents is 10.2 million units, and the daily output is 7.6 million copies, an increase of 58 times from January.

\subsection{Method}

This article uses research and online data search to conduct multi-dimensional research. The research conclusions of existing scholars on the development of enterprises under the new crown epidemic are mostly based on quantitative research. This article draws conclusions based on qualitative and quantitative analysis so that it can fill the gaps in the industry.

The case study method is particularly suitable for this study for three reasons. First of all, this research aims to study how the disinfection product market develops under the new crown epidemic. It is also appropriate to use case studies to describe the process of changes in the disinfection product market. Second, the purpose of this research is to systematically explore the internal advantages, internal disadvantages, external opportunities, and external threats of the development of disinfection products. Most of the existing research in academia is based on abundant data quantitatively, and this research can fill up the gaps in the academic world by using qualitative methods through SWOT analysis of disinfection products. Third, the research on the market development of disinfection products in academia is still very limited, and it is in the exploratory stage. This study explores the advantages, disadvantages, opportunities, and challenges of disinfection product market development during the epidemic, and provides development ideas for disinfection product manufacturers after the epidemic and helps them to point out the direction of development. Exploratory case studies are especially suitable for all new or existing academic fields that lack adequate research.

There are three reasons for choosing disinfection products as the research object. First, disinfection products performed more prominently during the epidemic when the sales volume of disinfection products increased rapidly, and stocks were often out of stock; second, existing scholars had less research on the development status of the 
disinfection product industry; third, the combination of disinfection products and new categories developed by enterprises can prompt people to study new development strategies.

In summary, this study mainly uses the SWOT analysis method to analyze the development advantages and disadvantages of domestic hot-selling disinfection products and their manufacturers during the epidemic, discuss their future development opportunities and challenges, and propose corresponding strategies and measures, to provide an effective basis for enterprises to respond to the normalization of the epidemic.

\section{Results and Discussion}

\subsection{SWOT analysis of disinfection products}

Under the new crown pneumonia epidemic, the disinfection product market has undergone a huge adjustment. SWOT analysis method is a research method that can objectively and accurately analyze and study the development status of an organization or unit, analyze and evaluate the advantages and disadvantages of disinfection products, as well as external opportunities and challenges (see Table 1).

Table1. SWOT analysis chart of disinfection products industry

\begin{tabular}{|c|c|}
\hline $\begin{array}{l}\text { Advantage } \\
\text { 1. The epidemic promotes the } \\
\text { rapid development of } \\
\text { disinfection products } \\
\text { 2. Export of disinfection } \\
\text { products }\end{array}$ & $\begin{array}{l}\text { Disadvantage } \\
\text { 1. Fake and shoddy products } \\
\text { emerge in endlessly } \\
\text { 2. Enterprise development is at } \\
\text { an intermediate stage } \\
\text { 3. Insufficient product } \\
\text { innovation }\end{array}$ \\
\hline $\begin{array}{l}\text { Opportunity } \\
\text { 1.Increase trade between } \\
\text { domestic and foreign enterprises } \\
\text { 2. Sales of disinfection products } \\
\text { increase corporate profits } \\
\text { 3. The production of disinfection } \\
\text { products provides many jobs } \\
\text { 4. Promote the development of } \\
\text { air disinfection industry } \\
\text { 5. Promote the development of } \\
\text { UV disinfection industry } \\
\text { 6.Accelerating the rise of } \\
\text { professional killing companies } \\
\text { 7. Expand the scope of product } \\
\text { application }\end{array}$ & $\begin{array}{l}\text { Challenge } \\
\text { 1.Lack of product } \\
\text { competitiveness } \\
\text { 2. Lack of brand } \\
\text { competitiveness } \\
\text { 3. Disorderly competition in } \\
\text { the market } \\
\text { 4. Produce products of } \\
\text { different grades }\end{array}$ \\
\hline
\end{tabular}

\subsubsection{Internal advantages of disinfection product development}

The epidemic has promoted the rapid development of disinfection products. At the beginning of 2020, the new crown virus broke out globally. Epidemiologists proposed that disinfection products, such as alcohol, can kill the virus. Therefore, in order to avoid contracting the new crown virus, people began to buy various disinfection products, which temporarily caused the supply of products to exceed supply. Therefore, enterprises quickly resumed work and worked overtime to produce products. The population of China is huge, and the demand for disinfection products is much higher than that of other countries. Therefore, the annual output increases, the production capacity expands, and the scale of the enterprise and the market also expand. In supermarkets and e-commerce platforms, it is not difficult to find that in addition to the original $75 \%$ alcohol and 84 disinfectant, many new products with different varieties and functions have been produced.

A large number of disinfection products are exported. At present, the overseas epidemic situation is severe, and the demand for disinfectants in many countries has increased sharply, especially in Europe and the United States. Domestic disinfectant manufacturers are gradually extending product supply to overseas markets while meeting domestic market demand. Due to the time difference between China and the international epidemic, when the domestic epidemic began, European and American countries did not produce a large number of disinfection products, so that after a large number of confirmed cases were found, the company stopped production, and various disinfection products and antiepidemic materials could not meet the huge market demand. Foreign companies began to buy Chinese disinfection products in large quantities. Until April this year, China has exported at least 1 million bottles with a cargo value of 1.3 million US of disposable disinfectant, 500 boxes of 3,000 cans of $70 \%$ disinfectant alcohol, sales of masks at 8.384 billion yuan, and a year-on-year increase in mask production peaking at 12 times, the output of medical instruments and equipment, and alcohol increased by more than $50 \%$. In the future, disinfection product manufacturers should experience low-quality products, many varieties, and high-quality products during the epidemic. Researchers should also increase research investment, upgrade traditional products, and develop disinfection that has a strong sterilization effect and does not harm the body. [5-7]

\subsubsection{Internal disadvantages of the development of disinfection products}

Counterfeit and shoddy products emerge in endlessly. The outbreak of the new crown epidemic has prompted a sudden increase in the demand for disinfection products from all walks of life. During the shutdown of various disinfection product manufacturers, this phenomenon has caused a shortage of disinfection products for epidemic prevention and control in a short time. At the same time, it took a loophole for individual companies. When the production conditions did not meet the relevant requirements, and the sanitation license was not obtained, some firms cut first and then played back. The disinfection products used for epidemic prevention and control were produced without a license such as the sterilization effect of the disinfectant that is not up to the standard. For example, the mask is only a thin layer, and the hygiene of the production workshop is poor.

Enterprise development is at an intermediate stage. With the outbreak of the epidemic, companies producing disinfection products have sprung up exuberantly, and market competition is fierce, attracting the attentions of 
the government and the public. Therefore, the government should introduce some policies to intervene in the development of enterprises, merge small and micro enterprises, eliminate the fittest, optimize the allocation of existing social resources, and promote the development of excellent enterprises.

Insufficient product innovation. The development of new products for enterprises should implement the safe, non-toxic, and environmentally friendly requirements of chemical disinfection products, instead of blindly emphasizing the new concept of high efficiency and quick effect. Make full use of physical factors can overcome the side effects of chemical disinfectants. Physical disinfection products pursue low-level, energy-saving, environmental protection and safety, to achieve perfect quality control and humanized promotion, emphasizing scientific, effective, and humanized use and traceability management. At the same time, product packaging lacks humanistic care, and more emotional, cultural, and aesthetic connotations should be given to the design so that the product and packaging can better serve the people [8-9].

\subsubsection{External opportunities for the development of disinfection products}

Increase trade between domestic and foreign enterprises. The company has broadened its sales channels, increased its market share, and strengthened its cooperation with international customers. As the new coronavirus epidemic continues to spread globally, there is a shortage of medical supplies. In particular, the demand for anti-epidemic materials, such as masks for new coronavirus detection kits, is strong. From the perspective of performance, the export of disinfection products will bring the company's performance growth and effectively boost the company's annual performance. At the same time, it must also increase the conversion rate of ecommerce to improve performance. Enterprises choose appropriate marketing platforms according to their own characteristics, and both internally and externally improve platform construction and promotion. After selecting the platform for marketing, the first thing needed is to do a good job of internal strength training. On the one hand, do a good job of filling and organizing the content of the website or online store, and transmit the necessary information, such as product information, to visitors and potential customers of the platform clearly and intuitively; on the other hand, do a good job for the construction of the guidance module mentioned above so that customers who are interested in placing orders can easily contact the company and order online. From the perspective of customer relations, through this epidemic, it can be found that existing customers will continue to use products and services to meet their needs as much as possible, or even exceed their expectations. Therefore, during the normalization of epidemic prevention, the company that continues to cooperate with foreign companies, attach importance to changes in customer needs, provide them with appropriate anti-epidemic products, establish lasting customer relationships, maintain stable cooperation, and bring a greater share of the business to the company.

The production of disinfection products provides many jobs. With the outbreak of the new crown epidemic, society's demand for disinfection products has risen sharply. Companies have increased their productivity and production lines, as well as provided many jobs. Therefore, jobs are provided to the unemployed people to ensure their basic lives and alleviate the gap between the rich and the poor, and to improve the quality of their lives. Take a company in Urumqi as an example; during the epidemic prevention and control period, this company increased the production of disinfection products, provided many jobs, solved the employment problem of poor local households, and also promoted stable income growth. Increasing jobs by enterprises, providing employment opportunities for local residents, alleviating the gap between rich and poor, are all effective ways to eliminate poverty in a large scale. At the same time, the work platform provided by the company can enable unemployed people to learn new technology, help their own development, fully develop existing human resources, improve social integration, and ensure the healthy and stable development of the economy and society [10-12].

Promote the development of the air disinfection industry. Affected by the epidemic, the state promotes the development of the air disinfection industry to provide livelihood guarantee for the normalization of epidemic prevention. Last year, at the National People's Congress, $\mathrm{Su}$ Ronghuan, a representative of the National People's Congress, put forward the proposal to "be the first to deploy a global airborne microbial epidemic prevention and control industry"; this year, during the National People's Congress, and the Chinese People's Political Consultative Conference (CPPCC), he continued his antiepidemic thinking and proposed the idea of "promoting the development of the air disinfection industry and enhancing the airborne epidemic, prevention and control system". During the epidemic, the Ministry of Finance of the People's Republic of China increased the investment in air disinfection infrastructure equipment, especially in the field of air disinfection, such as subway air supply disinfection, central air conditioning disinfection, elevator disinfection, public toilet disinfection, etc.; and domestic air prevention and control equipment should be installed with industry standards and have higher compulsory standards. It is stipulated that the air supply system in public places should have an emergency mode of active prevention and control to provide sufficient protection for future life. Nowadays, the air supply system of Guangzhou subway station has taken the lead in using air disinfection equipment. In the future, the National Development and Reform Commission will prioritize the deployment of epidemic prevention and control equipment in newly-built hospitals, schools, stations, terminals, airports, etc. through industrialized funding support. Public places, especially the promotion of the upgrading and transformation of the disinfection device of the air supply system in public places, should increase the emergency disinfection capacity of the system.

Promote the development of the ultraviolet (UV) disinfection industry. The new crown epidemic helped the application of the UV disinfection industry to people's 
daily life. In the "New Coronavirus Pneumonia Diagnosis and Treatment Plan (Trial Version 6)", it is pointed out that the virus is sensitive to ultraviolet light. The UV disinfection prevention and control industry has taken a big step in the epidemic, and some companies have expanded their scale and influence. For example, the Guangzhou subway and other public places have adopted UV disinfection prevention and control systems, but the domestic understanding of the new combined UV disinfection technology is still incomplete, which hinders the further application of this technology. A few years ago, Russia combined high-efficiency UV technology with air conditioning systems for rail transit epidemic prevention and control, and German companies also actively employed new UV technology in the air supply system. The national industry, information, and development and reform departments should introduce special technology projects (such as high-power, low-pressure and highintensity UV lamps, LED UV lamps, UV disinfection technology, the application of UV disinfection technology in air disinfection, etc.) to support the policies for UV disinfection air epidemic prevention technology, and speed up the design and implementation of supporting, incubation and industrialization promotion policies.

The rise of professional disinfection companies has accelerated. During the epidemic, professional disinfection companies ushered in new opportunities for development. Nowadays, developed countries in the world have implemented or partially implemented thirdparty medical disinfection and sterilization platforms. In contrast, most medical institutions in China use disinfection supply centers as the core departments to ensure the operation of hospital medical services. The level of disinfection control technology varies. Together, operating and management costs have increased greatly. Driven by the national policy assistance and the hospital's internal operating cost control, and driven by the epidemic, the hospital's disinfection supply center is gradually implementing service outsourcing. Since on June 11, 2020, some employees of Beijing Xinfadi have infected the new crown virus, and many supermarkets and vegetable markets in Beijing hired professional disinfection companies to carry out professional disinfection work. In the future, more and more public places will hire professional disinfection companies for regular and systematic disinfection work.

\subsubsection{External threats to the development of disinfection products}

The development of disinfection products in China is prosperous, but there are also many external threats. First of all, China's disinfection products lack product competitiveness. The types of disinfection products in China are ordinary, and the new products and boutiques on the market always imitate foreign products. These companies do not set a clear position for their own products, and sacrifices everything over-confidently, which directly lead to insufficient competitiveness in the market. Therefore, companies need special, multi-purpose and professional products, environmentally friendly and safe products, and food-grade harmless products. In the future, large enterprises, especially the leading enterprises in the industry, must act in accordance with the objective laws of industrial development and make real efforts to achieve breakthroughs in key technologies. Otherwise, there will be no way to success. Companies should rely on China's huge domestic market to formulate industry technical standards to improve product competitiveness. Second, China's disinfection products lack brand competitiveness. Creating a brand requires not only investment in certain financial resources but also product competitiveness and the comprehensive competitiveness shown by an excellent marketing team and brand planning team. Therefore, there are no well-known brands and wellknown disinfection companies in the domestic disinfection industry. At the same time, there is a disorderly competition in the disinfection product market in China. The domestic market for disinfection products is not standardized enough. Some companies change their business models by scoring policy and fight for market share. As a result, companies hurt each other, and the market is chaotic, forming disorderly competition in the disinfection product market and affecting the market's healthy growth. Finally, sanitizing products companies should produce products of different grades to meet different consumer needs. Enterprises should produce low-end disinfection products and mid-to-highend products so that less wealthy families can also carry out better daily disinfection [13-15].

\section{Conclusion}

The government should guide enterprises to make conscious transformations according to the characteristics of different periods. When market demand is strong, the government should guide largerscale enterprises to work overtime to produce disinfection products; when market demand decreases, the government guides large-scale production enterprises to transform to produce other products, while small-scale production enterprises start to produce stable daily needs productions. At the same time, the government provides assistance to corresponding enterprises, especially small and micro enterprises. The government should set up corresponding corporate subsidies to provide more preferential policies to the companies that have performed well in the epidemic.

During the epidemic, companies should adjust their product structure in response to market demand, carry out technological innovation, and form a multipillar product structure. Enterprises are speeding up the adjustment of product structure to meet market demand. Companies took advantage of the outbreak of the epidemic to quickly adjust product structure, broaden product categories, and occupy the consumer market. The rapid development of global science and technology will inevitably lead to the shortening and accelerating the replacement cycle of high-tech products and traditional products. It is not only pressure, but also a driving force for the adjustment of the product structure of enterprises, and it is a challenge and an opportunity as well. To 
maintain a rapid, sustained, and efficient development momentum, an enterprise must maintain a reasonable frequency in product structure adjustments to form a reasonable rhythm. From the actual situation of wellknown domestic and foreign enterprises, the proportion of new product sales revenue in the total sales revenue of the company should not be less than $20 \%$, and to ensure that the company's new and old pillar products are replaced and connected in time. During the epidemic, people's demand for disinfection products, especially 84 disinfectants, alcohol, air disinfector, disinfection cabinet, and other products that are favored by consumers, soared. Enterprises take the initiative to carry out technological innovations on existing products. Enterprises should carry out technological innovation, improve existing products, produce safer, environmentally friendly and efficient disinfection products, and enhance product competitiveness. The enterprise forms a multipillar product structure. Companies realize that abandoning the business model of a single product structure and forming a multi-pillar product structure can improve their ability to withstand market fluctuations.

Companies can choose their own positioning strategy and set product differences based on their sales conditions during the epidemic. First of all, companies should consider whether consumer groups can afford more expensive disinfection products, especially some poor people who live in rural areas and towns. Therefore, enterprises should produce products of the same quality but at low prices to meet the needs of consumers while occupying the low-end consumer market. At the same time, disinfection product manufacturers should also target high-end consumers, produce highquality products at more favorable prices, provide the highest-end products, and charge higher prices to compensate for higher costs.

\section{References}

1. LIU Hai - bing, XU Qing - rui. Latecomer firms strategy evolution, innovation paradigm and capabilities evolution [J]. Studies in Science of Science, 2018, 36(8): 1442-1454.

2. QIU Guofang, CUI Yafeng, ZHANG Xiaoqi. Corporate Strategy Development Based on SWOT Analysis Method [J]. Science and Technology Management Research , 2015, 35(018):193-196.

3. YE Tian-hong. SWOT Analysis and Strategy Research of Chinese Fast-Food Enterprises [J]. Management Research , 2017, 500(04):27-30.

4. WAN Jing. Analysis of Development Strategy of Logistics Enterprises Based on SWOT — Taking Shunfeng as an Example [J]. LOGISTICS ENGINEERING AND MANAGEMENT , 2019(8).

5. SUN Jing, SHEN Zhiyu. Business Model Design and Enterprise's Competitive Advantage-Moderating Role of Competitive Strategy and Slack Resources[J].Research on Economics and Management, 2015, 000(011):115-122.

6. WANG Bai-qiang, HOU Can-ran, SUN Jian. The
Impact of Business Strategy on Corporate Performances [J]. China Soft Science Magazine , 2018.

7. HONG Tao.On Enterprise Brand Positioning Enlightenment of Brand Positioning Strategy of "Liuyang River"Liquor Company [J]. JOURNAL OF CHANGSHA UNIVERSITY, 2018.

8. FAN Xiaojun, WANG Chengfu, LIU Yan. Positioning and channel effects of store brands under the condition of cost difference $[\mathrm{J}]$.Systems engineeringtheory \& practice, 2018, 38(8):2006-2017.

9. Lin Fangqiang Wang Lujie. Government Behavior Optimization Based on the Enterprise Competitive Strategy [J]. Chinese Public Administration , 2015, 000(006):92-96.

10. JIANG Han-chun, WANG Xiao-gu, ZHAO Hongying, JIANG Su-han. Studies on the Competitive Capacity and Tactics of Chinese Tea on the Overseas Market with SWOT Method [J].Journal of Tea Science, 2019, 24(3): 159-165.

11. LI Bo, SUN Lihua. Development Strategies of National Medicine Corporate Based on SWOT Analysis[J].Chinese Journal of Pharmaceuticals, 2018, v.49(02):144-148.

12. Xie Runmei, Chen Feng. Research on the Competitive Strategy Making by Online Education Enterprise Based on the Competitive Situation Analysis_- Taking Enterprise A as an Example [J]. Journal of Intelligence , 2016, 35(05):113-118.

13. MA Fang, LIU Yaling, LI Xiaoying. Research and analysis on CRM systems on mult-category fashion retailers [J].Shanghai Textile Science \&Technology , 2015, v.43;No.387(09):95-97.

14. CAO Yun-chun, XU Cheng. Strategic Suggestion for the Development of E-Commerce Enterprises of China in the Context of "Internet + " [J]. Prices Monthly, 2017, 000(007):64-68.

15. HUANG, You-wen. Study on Fresh Products Electronic Commerce Logistics in China Based on SWOT Analysis [J]. Storage and Process, 2017. 